\title{
Geology of Minerals of the Urengoy Deposit
}

\author{
Valeev A. I. \\ Affiliated branch of Ufa State Petroleum Technological \\ University in Oktyabrsky \\ Russia, the Republic of Bashkortostan \\ Oktyabrsky \\ valeev.aip@mail.ru
}

\author{
Kuzmina V.V. \\ Affiliated branch of Ufa State Petroleum Technological \\ University in Oktyabrsky \\ Russia, the Republic of Bashkortostan \\ Oktyabrsky \\ vvv220491@mail.ru
}

\author{
Almukhametova E.M. \\ Affiliated branch of Ufa State Petroleum Technological \\ University in Oktyabrsky \\ Russia, the Republic of Bashkortostan \\ Oktyabrsky \\ Elikaza@mail.ru
}

\author{
Anisimov V.V. \\ Affiliated branch of Ufa State Petroleum Technological \\ University in Oktyabrsky \\ Russia, the Republic of Bashkortostan \\ Oktyabrsky \\ vlad2909@mail.ru
}

\begin{abstract}
The territory of the Urengoy deposit is characterized by the instability of thermodynamic equilibrium of geological environment, due to the existence of permafrost. The article investigates the geological section of the area, its oil and gas potential, analyzes the geological and physical information. The oil and gas potential within the Urengoy oil and gas region is established in a wide stratigraphic range. The results of drilling and testing of exploratory wells are also presented. Almost all the deposits are complicated by tectonic screens, the presence of which is confirmed by the history of the deposit exploitation.
\end{abstract}

Ket words-Urengoy deposit, geology, oil and gas content, section, system, parameters, characteristics, rock.

\section{INTRODUCTION}

The Urengoy deposit consists of the Urengoy, YenYakhinskoy, Pestsov areas administratively located in the Purovsky and Nadym districts of the Yamal-Nenets Autonomous District. Yen-Yakhinskoy, Pestsov and northern parts of the Urengoy Square are located beyond the Arctic Circle. Gas production facilities are developed in Medvezhye gas field and Urengoy deposit. There are no other permanent industrial enterprises in this region.

The deposit was discovered in June 1966. The total geological reserves are estimated at 16 trillion $\mathrm{m}^{3}$ of natural gas and 1.2 billion tons of gas condensate. Residual geological reserves comprise 10.5 trillion $\mathrm{m}^{3}$ of natural gas and $65.63 \%$ of the total geological reserves of the Urengoy deposit.

The operating well stock of the Urengoy deposit contains more than 1,300 wells. "Gazprom Dobycha Urengoy" (formerly "Urengoygazprom") a limited liability company under the laws of Russian Federation, a 100\% subsidiary of "Gazprom". Natural gas production in 2007 comprised 223 billion cubic meters.

In December 2008, Gazprom Dobycha Urengoy passed into gas production at 6 trillion $\mathrm{m}^{3}$.

\section{DEPOSIT OVERVIEW, OIL AND GAS CONTENT}

Pestsov area is part of the fields of the Big Urengoy. Geographically, it is located in the south of the Tazov halfisland, in the northern part of the West Siberian Lowland. Administratively, it is located within the Nadym district of the Yamalo-Nenets Autonomous District of Tyumen Region [1].

The Urengoy, North-Urengoy and West- Pestsov areas of the Urengoy deposit are located in the southern part of the northern permafrost zone, where permafrost rocks are spread throughout the area and vertically.

The top of permafrost is located at a depth of $0.2-0.5 \mathrm{~m}$ in organogenic soils and 1-3 $\mathrm{m}$ in mineral soils.

The bottom of permafrost is located at the top of the TibeiSalinsk deposits at depths of 338-420 m.

Above the section, the frozen stratum includes clay deposits of Lyulivorsky and Chegan series, sandy deposits of the Nekrasov series and clayey and sandy-clay quarters. The permafrost formations are possible under the lakes (from 3-5 to $10-15 \mathrm{~m}$ deep), the interfrost - under the drained lakes.

The depth of seasonal thawing varies from 0.5 to $1.5 \mathrm{~m}$. Seasonal thawing continues from the end of May to the beginning of October [2].

Permafrost is characterized by high ice content, has a layered and reticular, less often massive cryogenic texture. Down the section the ice content decreases. Bulk ice content varies from 35 to $45 \%$ in mineral soils, in the end reaches $80 \%$ and more. Thermokarst is widely developed among cryogenic processes, which manifests itself in the formation of thermokarst lakes and polygonal landforms. Often there are hummocks of long-term swelling. Their height varies from 1.5$2.0 \mathrm{~m}$ to $7-8 \mathrm{~m}$. In the valleys, thermo-erosive gully-forming processes are developed. The length of the gullies reaches 100 - 250 meters [3]. 
The average annual temperature of permafrost varies from 3 to $5^{\circ} \mathrm{C}$ below zero at the watersheds and from 1 to $3{ }^{\circ} \mathrm{C}$ below zero in river valleys. Zero geoisoterm can be traced at 13 - $80 \mathrm{~m}$ below the bottom of permafrost.

Due to the flat terrain and close bedding to the surface of permafrost, almost the entire surface is over-wetted and swamped. Marshes, mainly peaty, flat-hilly, with shrubslichen-moss cover on the hills, grass-moss covers in hollows. Among the lake-marsh spaces, there are often extensive drained lakes with a diameter of $1.0-1.3 \mathrm{~km}$. The thickness of lakemarsh sediments does not exceed $2 \mathrm{~m}$. In general, the areas of considered fields are characterized by complex engineering and geological conditions for the development due to waterlogging, logging, surfaced and permafrost with a cryogenic process.

In terms of climate, the area is attributed to the regions of the Far North and is located beyond the Arctic Circle. The exploitation area is a boggy low-hilly plain with a large number of small rivers and lakes, which is associated with the presence of permafrost and close occurrence to the surface of waterresistant rocks. The shape of the lakes is often isometric, the depth is $2-3 \mathrm{~m}$, the shores are low, and sometimes they are steep. The watersheds are flat, the river valleys are narrow. Frozen landforms are marked on the watersheds: thermokarst lakes, peaty hummocks of swelling. The absolute relief elevations of the square differ from $+18 \mathrm{~m}$ to $+80 \mathrm{~m}$.

Rivers and lakes are covered with ice in early October, in late November - early December the ice becomes strong (up to $1.5 \mathrm{~m}$ thick).

The climate of the region is sharply continental, with a harsh long winter and very short summer. The coldest months are January and February with an average temperature from $-24^{\circ}$ $\mathrm{C}$ to $-28^{\circ} \mathrm{C}$. The minimum temperature reaches $-63^{\circ} \mathrm{C}$. The winter is frosty, with winds and lots of snow. The height of snow cover reaches $82-100 \mathrm{sm}$, in lows - up to $2 \mathrm{~m}$. Snow falls in the first decade of October. Snow cover lasts 210-250 days. The predominance of the wind direction in winter is south-west, in summer - north and north-west. Wind speed does not exceed $10 \mathrm{~m} / \mathrm{s}$. The average monthly temperature in July is $+14{ }^{\circ} \mathrm{C}$, maximum $+34^{\circ} \mathrm{C}$. The average annual temperature is $+7.8^{\circ} \mathrm{C}$. Annual rainfall is $350 \mathrm{~mm}$. Most of them fall in the warm season [4].

Within the area the thickness of permafrost has a widespread and continuous distribution. The bottom of the permafrost is located at a depth of 340-406 $\mathrm{m}$ in the tops of sediments of the Tibeysal Formation. Above the thickness of permafrost, the seasonal thawing layer occurs; its depth varies from $0.5 \mathrm{~m}$ to $1.5 \mathrm{~m}$. Seasonal thawing continues from the end of May to the beginning of October. The average annual temperature of permafrost varies from $-3^{\circ} \mathrm{C}$ to $-5^{\circ} \mathrm{C}$ at the watersheds and from $-1{ }^{\circ} \mathrm{C}$ to $-3{ }^{\circ} \mathrm{C}$ in the river valleys. Due to the close bedding to the surface of permafrost, almost the entire surface is over-wetted and swamped [5].

The forest cover in the deposit is poorly developed. The flora is typically of tundra - moss bogs with rare thickets of dwarf willow and birch. Coniferous trees (Siberian spruce, larch) grow along the banks of rivers and streams.
The population of the area is rare. The indigenous population is Nenets, Khanty, Selkup, Russians. The main occupations of the local population are hunting and fishing. The exploration works are carried out, the gas industry is developed on the territory of the field.

Directly on the territory of the deposit there are no settlements. The nearest settlements are Sumburgh, Tazovsky, Tarko-Sale and Novy Urengoy.

The main routes of communication are air, road and rail. The Surgut - Urengoy - Novy Urengoy - Nadym and Novy Urengoy - Yamburg railways pass in the immediate neighborhood of the deposit.

The nearest existing gas pipelines are "Medvezhye-Center", "Urengoy-Uzhgorod", "Urengoy-Chelyabinsk" [6].

The Urengoy oil and gas condensate deposit is located in the northern part of the West Siberian Lowland (Fig. 1). Administratively, the deposit is located in the Purovsky District of the Yamalo-Nenets Autonomous District. The territory of the deposit is a very swampy, slightly hilly plain.

The territory of the Urengoy deposit is characterized by the instability of the thermodynamic equilibrium of the geological environment, due to the existence of permafrost.

Directly at the Urengoy deposit, gas, condensate and oil are extracted from the Cenomanian, Valanginian, Achimov deposits. For the preparation of gas and condensate for transport, integrated gas treatment units (IGTU) were built. Primary condensate processing is carried out at the Urengoy plant (condensate pre-transportation preparation plant).

According to the tectonic scheme of the Mesozoic-Cenozoic sedimentary cover of the West Siberian Plate, the Urengoy deposit is located within the first order structure - the Nizhnepursky megaswell, which is an elevated zone with a length of $235 \mathrm{~km}$ with a width of $55 \mathrm{~km}$ extended in a sublatitudinal direction with local uplifts order - West Pestsov, Pestsov, En-Yakhinsky, Urengoy and North Urengoy. In the West, the Pestsov shaft closes in with the Medvezhye Yamburg megawal, and in the east with the Bottom - Pursky. In the north, the shaft is bounded by the Kadutteyskaya depression, in the south - Nerutinskaya. From the south, a chain of small local elevations (South Pestsov, TabyakhoTarkosalinskoe, and others), united in a structural element of the second order - Tarkinsky shaft, adjoins the Pestsov Val shaft. The North-Urengoy uplift is located within the Oikuminsky shaft and is a dome-shaped fold of east-west trending [7].

The Urengoy structure has a north-south strike, the EnYakhinskoy structure has a northeast strike, the Pestsov range is latitudinal, the North Urengoy structure is sublatitudinal, the West Pestsov - latitudinal.

All areas are contoured with isoheight minus $1200 \mathrm{~m}$. 


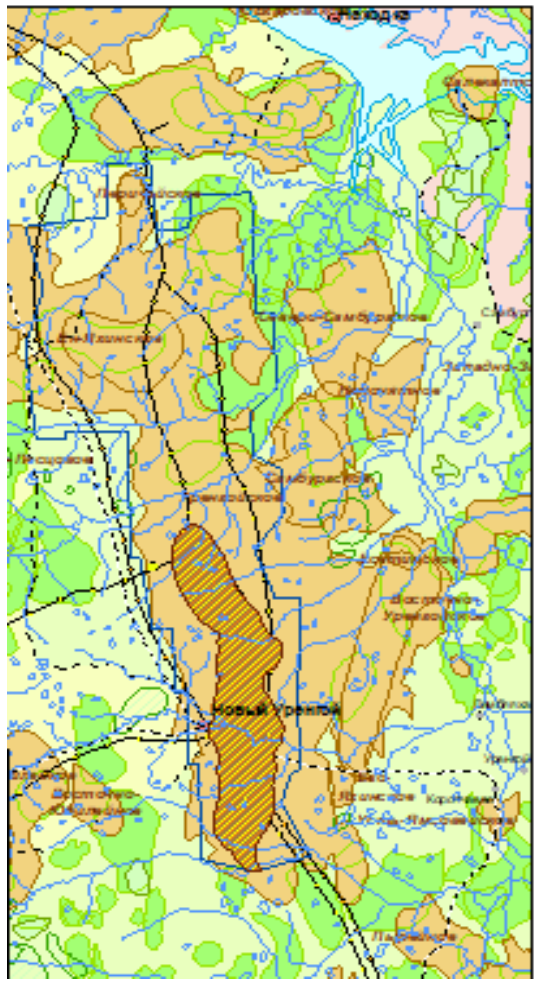

Fig. 1. Region overview map

The oil and gas potential within the Urengoy oil and gas zone has been established in a wide stratigraphic range: from the Cenomanian stage of the Upper Cretaceous to the Toarian stage of the Lower Jurassic sediments. The deposits in the Neocomian sediments and the Achimov layer often have oil rims.

Due to the similarity of the facial conditions of sediment accumulation, the formation of traps and deposits of oil, gas, gas condensate, having similar properties and parameters within the specified stratigraphic range in the Urengoy region, five oil and gas bearing complexes are distinguished from bottom to top: Lower - Middle Jurassic, Upper Jurassic, Achimov, Neocomian (Valanginian), Cenomanian:

I object (layers PK18, PK19, PK210, PK21, AU9, AU101, AU 102, BU0, BU1-2, BU5, BU6) -20 gas-condensate deposits;

II object (layers BU 80, BU 8, BU 9) -17 deposits;

III object (layers BU 101, BU 102, BU 111, BU 112, BU 113, BU 121) -38 deposits;

IV object (layers BU 122, BU 13, BU 141, BU 141-1, BU 142) -21 deposits;

$\mathrm{V}$ object (formations BU 160, BU 161-1, BU 161-2, BU 161-3) -7 deposits.

The main hydrocarbon reserves are contained in formations BU80-BU14 [8].

One of oil and gas objects in the exposed part of the section within the considered territory is the Achimov stratum of the lower Cretaceous.
The complex is distinguished in the volume of the same name stratum, which lies at the base of the high grade suite. According to seismic exploration and exploration drilling data, the Achimov formations have a lenticular intermittent distribution, formed under conditions of avalanche sedimentation and are the foundation-form parts of the Valanginian clinoform complexes Ach6 - BU20, Ach60 BU19, Ach5 - BU18, Ach3-4 -BU20, Ach60 - BU19, AchBU20, Ach60 - BU19, Ach-BU20, Ach60 - BU19, Ach-BUU, Ach60 - BU19, Ach-BUU, Ach60 -BU19, Ach6 - BU Ach12-U16.

The oil-and-gas bearing reservoir Ach6 is developed on the East Urengoy + North-Esetinskaya, Esetinskaya and EvoYakhinskaya areas, on the eastern slope of the Urengoy swell, Ach60 - the eastern slope of the Urengoy embankment, on the Yesetinskaya, North-Esetinskaya, Neponyatnaya and Sumburgh areas, Ach5 - on the eastern slope of the Urengoy embankment, on the Yesetinskaya, East-Urengoy, Sambursk and North-Sambursk squares, Ach3-4 mainly in the arched part of the Urengoy embankment, on the Sambursk and NorthSambursk squares, Ach1-2 - to the west of Urengoy shaft slope, and Tabyakhinskoy and Khaduteiskoy squares [9].

Oil, gas condensate, gas condensate-oil deposits in reservoirs of the Achimov stratum are controlled by lithologictectonic blocks (areas restricted by the combined development of lithological and tectonic screens). Within individual blocks, the distribution of fluids is mainly associated with hypsometry.

The horizons Ach3-4, Ach5 are characterized by the largest size and increased productivity. The average flow rates of the gas-condensate compound in the study at various modes in many wells exceed 400 thousand $\mathrm{m} 3$ / day, and the flow rates of stable condensate vary from 80 to $150 \mathrm{~m} 3$ / day, at the same time, some areas are characterized by low-energy properties and, when tested, give low-rate inflows of gas condensate.

The Achimov oil and gas complex is one of the most complex objects of the section. Sandy-aleuritic materials are not sustained in the latitudinal direction, but can be traced fairly well in the meridional direction, forming narrow zones of increased sandstone thickness (up to 40 and more m) with a total thickness from 90 to $100 \mathrm{~m}$, oriented from south to north.

Geological section of the layers Ach3-Ach52-3 along the line of wells 279-739-255-760-1A072-1A071-1A0331A042-1A043 - U0406 - U0503 - U0502-305ses - 301ses is shown in Figure 2.

\section{RESULTS}

According to the results of drilling and testing of exploration wells 20, 23, located on the Samburgsky area, operational hydrocarbon reserves were calculated for the Ach3, Ach4, Ach52-3 reservoirs of the Urengoy deposit [10], the reserves approved by the FAN protocol [7]. In 2012, the geological model of the Ach3, Ach4, Ach52-3 layers along with the position of fluid contacts in the Ach52-3 formation was specified in the bottom treatment. 


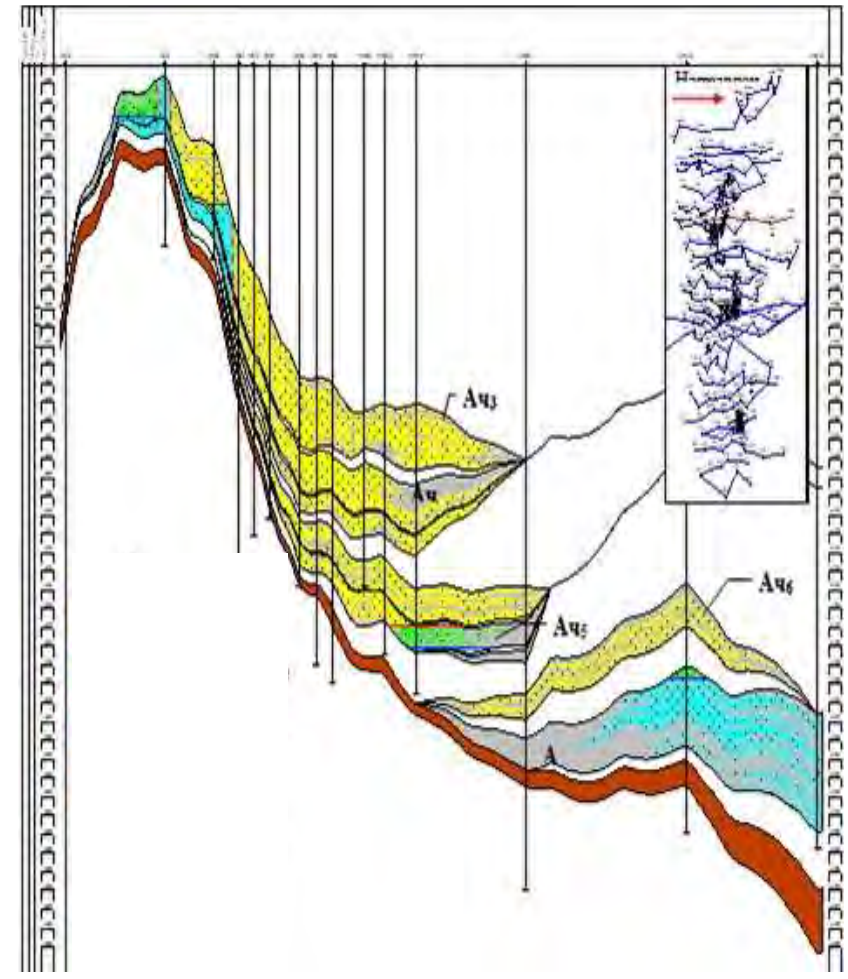

Fig. 2. Geologic strata section Ach3-Ach52-3

In 2013 on Samburgsky license area four exploratory wells (wells 25ur, 30ur, 31ur, 41ur) and 10 production wells were drilled, at Evo-Yakhinsky license area - one exploration well (well 81ejx), taking into account the information received, operational hydrocarbon reserves were calculated for the reservoirs of the Ach3, Ach4, Ach52-3, Ach61 layers of the Urengoy deposit $[8,9]$.

Hence, as the basis for building a digital geological model, materials from operational recalculations of reserves were used and examined by Rosnedra [11].

The production drilling is continuing at the deposit, as well as the study of sediment exploration wells. After the performance of operational recalculations of stocks as of $01 / 01 / 2015$ on the Urengoy license area 63 production wells were drilled (41 of them were in section 1A, 22 wells were in section 2A), in the East Urengoy three exploratory wells (wells 902, 904, 905 East Urengoy) and 13 production wells (bushes 206, 217,219 ) were drilled, on West-Yaroyakhinsky - one exploration well 412, on Novo-Urengoy - one exploratory well (well 931 Novo-Urengoy) and seven exploratory (bushes 109, 114) were drilled, on Samburgsky area - two exploratory (wells 26,62 ) and 30 production wells were drilled (clusters U01, U02, U05, U07, U10, U12, U17, U19, U20, U23). Currently, the production drilling is continuing in areas 1A, 2A of Urengoy and on Samburg license areas [12].

\section{CONCLUSION}

Analyzing the initial geological and physical information on Urengoy deposit, the following conclusions can be made:

Currently, 295 (including 58 after 1988) exploratory and 972 (including 494 after 1988) production wells have been drilled in the Lower Cretaceous deposits of Urengoy deposit. At the beginning of 2006, the territory of Urengoy gas condensate field is occupied with a dense network of seismic specialized observations. Among them, the most informative ones are the materials of surveys made after 1988 (3060 linear meters). Currently, about $70 \%$ of the deposit area is covered by seismic 3D CDP method (2,600 km2). Nowadays, 3D CDP are being carried out at the southern dome of the Urengoy gas condensate field (SP77 / 04-05). The other areas of volumetric seismic exploration, carried out from 1993 to 2003, cover the northern half of the field almost continuously or in overlapping mode. The accumulated geological and geophysical material indicates a much more complex structure of the Neocomian sediments than it appeared in 1989. In particular, 3D seismic surveys and the results of reservoir tests in exploratory and production wells allow adopting a block model of the structure of the Lower Cretaceous sediments. According to this model, almost all the deposits are complicated by tectonic screens, the presence of which is confirmed by the history of deposit exploitation.

\section{References}

[1] V.V Mukhametshin, "The need for creation of a unified comprehensive method of geological and field analysis and integration of data on effective influence on the bottom-hole formation zone", Neftyanoe Khozyaystvo - Oil Industry, 2017, № 4, pp. 80-84.

[2] V. Mukhametshin, V. Andreev, "Search and argumentation of decisions aimed at increasing the efficiency of bottom-hole zone stimulation in oil accumulations with challenged reserves", [SPE Russian Petroleum Technology Conference, the team of authors, Moscow.: Society of Petroleum Engineers, 16-18 October 2017]. DOI: https://doi.org/10.2118/187785-MS.

[3] A.V. Koshelev, "Analysis of the Efficiency and Directions for the Further Implementation of Hydraulic Fracturing in Oil Wells of the Urengoy gas condensate field", Geology, drilling, development and exploitation of gas and gas condensate fields, M.: IRTS Gazprom, 2003, №1.

[4] I.A. Blokhinsky, V.N. Moskvichev, V.N. Khozyainov, N.V. Rakhimov, S.V. Serebrennikov, A.A. Akhmetov, "New preparation program for Neocomian wells of Urengoy field to conduct hydraulic fracturing", Geology, drilling development and operation of deposits, M: Gazprom, 2003, No. 1

[5] W.M. Edmunds, P. Shand, M. Nedra, "Natural groundwater quality", 2008 .

[6] N.V. Koronovsky, "General geology", Moscow University, 2003.

[7] S. Adams, D. Lambert, "Earth Science: An Illustrated Guide to Science", CHP, 2006, p. 208.

[8] P. Abbott, "Natural Disasters", 10th Edition, McGraw-Hill, 2017.

[9] M. Allaby, “A Dictionary of Geology and Earth Sciences", 4th edition, Oxford: Oxford University Press, 2013.

[10] G. Borradaile, "Understanding Geology through Maps", Elsevier, 2014.

[11] D.H. Carlson, C.C. Plummer, L. Hammersley "Physical. Geology", McGraw-Hill, 2015.

[12] Urengoy deposit report, 2015. 